\title{
IMPACT OF COVID-19 ON E-BUSINESS IN NATIONAL CAPITAL REGION (INDIA)
}

\author{
Chahat Tandon, Ananya Arora, Anu Yadav \\ Student, Mata Sundri College for Women \\ Student, Mata Sundri College for Women \\ Assistant Professor, Mata Sundri College for Women
}

\begin{abstract}
E business is a model of business or transaction of commercial nature that includes sharing information across the internet. Since the outbreak of the corona virus pandemic there is an upward slope of E commerce graph and digital solutions. E commerce is most considered and chosen way of purchasing different types of products nowadays. Furthermore, during this pandemic, the norms of social distancing and staying at home are pushing the customers towards E business. This study has an objective to determine the growth of $E$ business due to the corona virus pandemic. This study examines the growth of e-business due to COVID-19 pandemic and also analyses whether e-business became the substitute source of traditional marketing or not. This study is based on primary data collected from more than 500 people residents of National Capital Region (India).
\end{abstract}

Keywords: Covid-19, Pandemic, Growth, E-Business

\section{INTRODUCTION}

Have you people heard others saying: "Mind your own Business."?

Yeah! I am sure at some point of time in your life you must have. So, first of all we need to know, what is a business?

Business generally refers to establishments that seek benefits by contributing goods or services in exchange for payment. In simple terms, business is something which is the work that a person or an organization does as a job.

Business can also be conducted online, i.e., online business or e-business. It is a kind of commercial transaction or business transaction which consists of sharing information over the internet. This can occur between a huge numbers of market participants, for example, between businesses and customers, public authorities or, any other organizations. The term e-business was termed by the IT Corporation IBM (International Business Machines) in 1996.

Now, as corporations continuously reconsider their businesses in terms of the internet peculiarly, the internet's accessibility, reach and ever-changing capabilities, they are conducting e-business to buy parts and supplies from other corporations, participate in sales promotions, and perform joint research.

In comparison to e-business, the meaning of e-commerce is clearer. Simply stated, it involves placing orders and making payments online. E-commerce sales can include every element of a sale i.e. ordering a product, paying for a product, and delivering it. It might also involve only some part of the process. For example, a customer might order a product online to be picked up at the shop. Payment might be conducted digitally or at the store when the item is selected. Either way, the transaction still involved a component of e-commerce. Some individuals think that the words e-business and e-commerce are interchangeable, but they aren't equivalent. E-commerce can be perceived as a subtype of e-business.

Through this research, we are making an attempt to analyze how much, during the corona virus pandemic; ebusiness has expanded in the National Capital Region of India. And, also that, how many people have actually switched to the online mode of business.

This research is based upon primary data collected by our team from 550 people of all age groups, gender, and region (urban / rural / suburban) of National Capital Region (NCR) of India.

\section{REVIEW OF LITERATURE}

Here's an attempt is made to briefly review the work already undertaken and methodology employed. A brief review of some studies has been presented below:

Tran and L.L.T. (2020) study adopted uses and gratification theory to base the visionary model while adding a boundary condition of pandemic fear. The leading research method of this study is a quantitative survey and analysis. Using a sample size of 617 consumers online with PLS analytical technique, this study finds a positive 


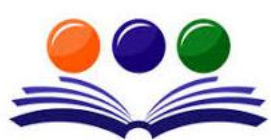

GRAND ACADEMIC PORTAL RESEARCH JOURNALS

A GLOBAL JOURNAL OF SOCIAL SCIENCES

( ISSN - 2581-5830 )

Impact Factor - SJIF - 4.998, IIFS - 4.375

Globally peer-reviewed and open access journal.

curbing effect of pandemic fear on the relationships among PEEP, economic benefits and sustainable consumption.

Bhatti et al. (2020) examines that E-business grew due to corona virus. E-business has become a substitute source and considered top in this condition and consumers bought in superstore traditionally. COVID-19 influenced entire E- business. Meanwhile we want to comprehend their efficiency to stabilize cost and benefits as well as connected actions in coming future.

Hasanat et al. (2020) the key purpose of this research is to determine the impact of corona virus on the online business in Malaysia. The results illustrated that as the maximum of the products came from China and the maximum number of industries are lockdown which means that there are no import and export of the products. Therefore, it is assumed that this venomous virus will severely impact the Malaysian online business especially the Chinese products.

Pantelimon et al. (2020) this study consists of two parts, the first one analyses the impact of the mobile business's growth on the Gross Domestic Product for both a West European country- Germany and the East European country - Romania from 2014 to 2019. The analysis aims to understand the motile business importance within the pre- COVID-19 era, in the context of stable economies. The second part studies the overall consumer behavior towards usual commerce and electronic commerce within the context of COVID-19 pandemic state. In this regards we analyzed data for January -April 2020 and studied the main changes for the countries which were either suffering from the pandemic, severely affected or both.

M. A. Salem and K. Md Nor, this study empirically assessed the factors that affect consumers 'intention to adopt e- commerce during corona virus disease 2019(COVID -19) in Saudi Arabia'. The 10 factors investigated in this study are perceived usefulness (PU), perceives ease of use (PEOU), subjective norms (SN), perceives behavioral control (PBC), perceived lack of alternatives, perceived risk, perceived punishable infractions, risktaking propensity, perceived external pressure and government support. Data was collected online among social media users by using the snowball sampling technique. A total of 190 valid responses were obtained. The data analysis showed that PU, risk taking propensity, PBC, perceived lack of alternatives and government support undoubtedly influenced consumers 'intention to adopt e-commerce during the COVID-19 outbreak in Saudi Arabia'. Meanwhile, PEOU, SN, perceived external pressure, perceived risk and perceived punishable infractions exerted insignificant effect on consumers 'intention to adopt e- business'.

\section{RESEARCH GAP}

Very few studies have been conducted on e-business market surge after COVID- 19 pandemic. The previous studies derived that the COVID-19 pandemic came up with high growth in the e-commerce market in nearly every product and services ranging from apparels, medical supplies, shipping, cleaning, and home entertainment to food items. The research based on e-business in the National Capital Region of India has not been conducted before. Through this research, we are making an attempt to analyze how much; during the corona virus pandemic e-business has expanded in the National Capital Region of India.

\section{RESEARCH METHODOLOGY}

\section{OBJECTIVE OF STUDY}

- To examine the growth of e business due to COVID-19 in NCR of India.

- To find whether e business has become a substitute for people and whether it is considered as the topmost priority in COVID- 19 pandemic or not.

- to observe the challenges faced in e business by the population of NCR.

\section{SOURCE OF DATA}

This research is based upon primary data collected by our team from 550 people of all age groups, gender, and region (urban / rural / suburban) of National Capital Region (NCR) of India. The responses were collected through Google forms. The URL for the same is attached below:

https://forms.gle/Q242LzTdYoZqErgx7

In depth responses from 550 individuals were taken. To gather respondents the survey invitation was sent to 750 references.

\section{E BUSINESS AND COVID 19 PANDEMIC}

COVID -19 impacted the whole E- business in the world. It has significantly changed the nature of doing business. Despite the COVID-19 crisis and economic downfall, the E- business industry in Delhi NCR experienced an upward shift during lockdown and post lockdown, contributing a $17.5 \%$ increase in the volume of demand during the lockdown. 


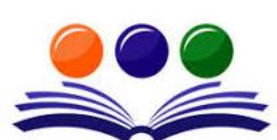

GRAND ACADEMIC PORTAL RESEARCH JOURNALS

\section{A GLOBAL JOURNAL OF SOCIAL SCIENCES}

( ISSN - 2581-5830 )

Impact Factor - SJIF - 4.998, IIFS - 4.375

Globally peer-reviewed and open access journal.

The responses were collected from 6 regions of NCR namely Delhi, Faridabad, Ghaziabad, Gurugram, Noida and others. Furthermore, $63.5 \%$ of respondents are female and the remaining i.e. $36.5 \%$ are males contributing $85.1 \%$ from urban areas, $9.6 \%$ from rural areas and $5.3 \%$ from sub urban regions.

City

550 responses

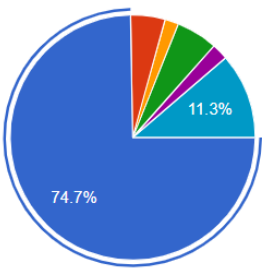

- Delhi

- Faridabad

Gurugram

Gurugran

Other

Fig 1.1 550 responses. Based on the question "city"

Resident of

550 responses

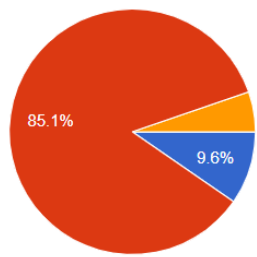

- Rural

Urban

Fig 1.2 550 Responses. Based on the question "resident of"
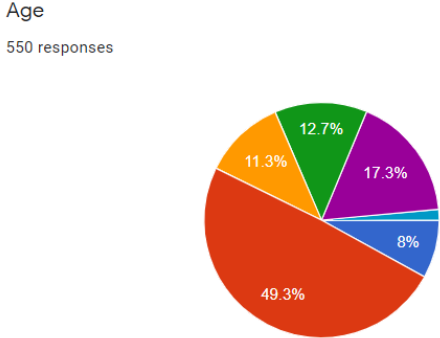

<18 years

$18-24$ years

25 - 34 years

35 - 44 years

- 45 - 60 years

$>60$ years

Fig 1.3 550 Responses. Based on the question "Age"

In depth from 550 respondents -

44 responses from the age group of less than 18 years, 271 responses came from the age group of 18-24 years, 62 responses from 25-34 years, 69 responses from 35-44 years, 95 responses from 45-60 years, 8 responses from the age group of more than 60 years.

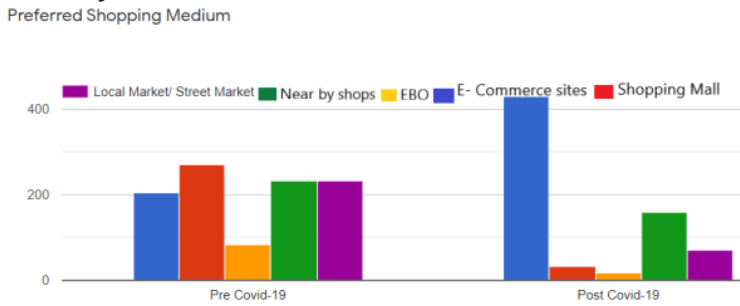

Fig 1.4 550 Responses. Based on the question "Preferred Shopping Medium”

The popularity of $\mathrm{E}$ - commerce sites increased after the advent of COVID- -19 pandemic. It was an increase of $40 \%$ and more from pre COVID- era till now and is expected to rise further. A decline in the percentage was noticed in the revenue for shopping malls, EBO, local /street market, and nearby shops. 


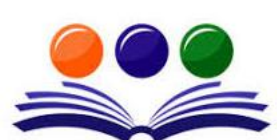

GRAND ACADEMIC PORTAL RESEARCH JOURNALS

\section{A GLOBAL JOURNAL OF SOCIAL SCIENCES}

( ISSN - 2581-5830)

Impact Factor - SJIF - 4.998, IIFS - 4.375

Globally peer-reviewed and open access journal.

Monthly Budget

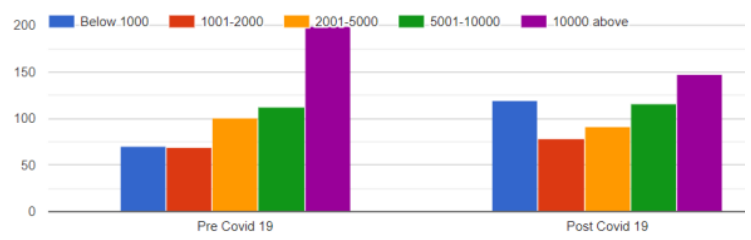

Fig 1.5 550 Responses. Based on the question "Monthly Budget"

The monthly budget of people ranging from ₹10000 and above declined with a percentage of 10 from pre COVID- era till post COVID- 19. Budget ranging from ₹5001-₹10000 noticed a minimal increase from $20.3 \%$ ( pre - COVID- 19) to $21 \%$ ( post COVID- 19). Budget ranging from ₹2001-₹5000 declined with a percentage of 1.8. Also the monthly budget ranging below $₹ 2000$ experienced a growth of $10 \%$.

Do you prefer E- Payment modes for paying the bills?

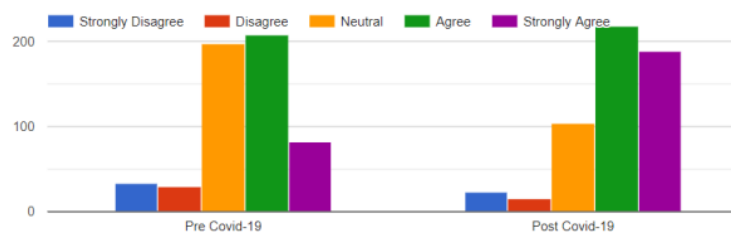

Fig 1.6 550 Responses. Based on the question “Do you prefer E-Payment Modes for paying the bills?"

Which mode do you prefer for receiving bills?

550 responses

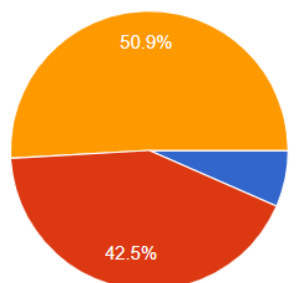

Both

Fig 1.7 550 Responses. Based on the question "Which mode do you prefer for receiving bills?"

Outbreak of corona virus has changed the consumer preferences for paying their bills from handwritten (manual) bills to E- payment modes. As 280 respondents preferred both the medium for receiving the bills in the pre COVID- period. But a sudden upsurge in the behavior of people noticed as they started preferring Epayment modes for paying bills. As in pre COVID-19 period only 82 respondents agreed on using electronic means whereas 189 people realized the importance for using such means to prevent the outbreak of corona virus.

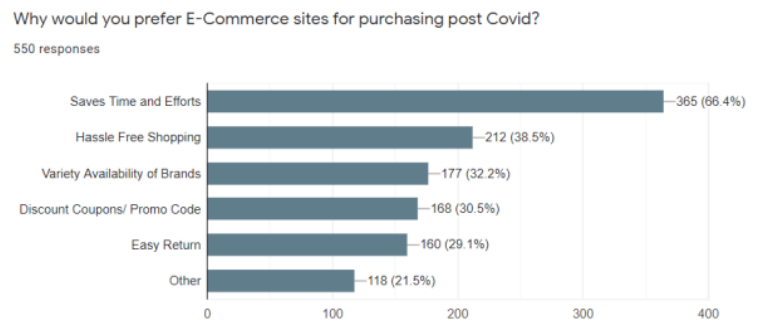

Fig 1.8 550 Responses based on the question "Why would you prefer E-Commerce sites for purchasing post Covid-19?" 


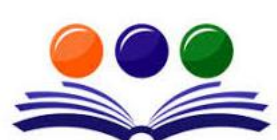

GRAND ACADEMIC PORTAL RESEARCH JOURNALS

A GLOBAL JOURNAL OF SOCIAL SCIENCES

( ISSN - 2581-5830 )

Impact Factor - SJIF - 4.998, IIFS - 4.375

Globally peer-reviewed and open access journal.

Do you prefer buying essential items online?

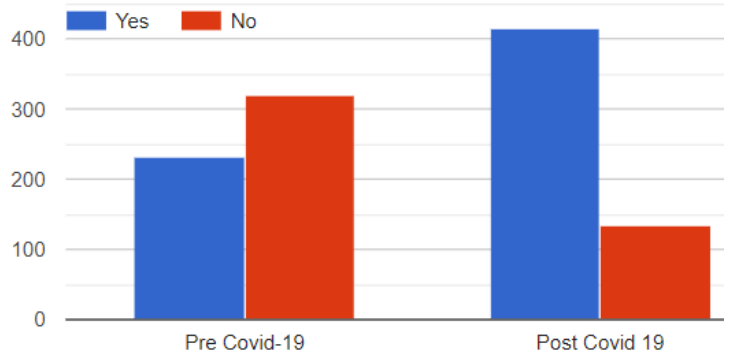

Fig 1.9 550 Responses. Based on the question "Do you prefer buying essential items online?"

In depth out of 550 responses, 365 respondents feel that using E-commerce sites for purchasing Saves their time and efforts, 212 people feel that it leads to hassle free shopping, 177 feel that it has wide variety of brands, 168 people feel that they most often receive discount coupons and promo codes while purchasing, 278 people feel that it has easy returns and other reasons for purchasing.

In pre COVID period $56.7 \%$ of the respondents didn't prefer buying essential items through online buying platforms, whereas a sudden shift in graph was noticed as $75.45 \%$ of the respondents felt comfortable in buying essential online in the post COVID-19 period.

Do E- Commerce sites provide you all the essential

information?

550 responses

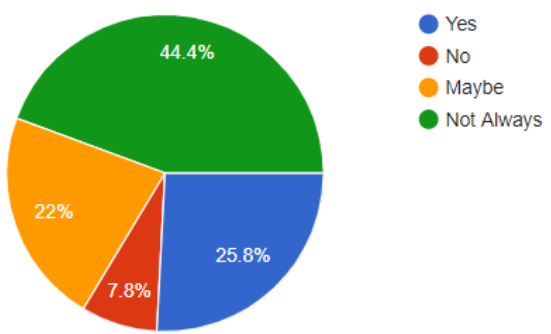

Fig 1.10 550 Responses. Based on the question "Do e-commerce sites provide you all the essential information?”

Although E - commerce industry contributed to the maximum revenue growth during the lockdown yet people faced difficulty in using such sites and fulfill their purpose. As 244 respondents out of 550 feel that E-commerce sites not always provide the all essential information whereas $22 \%$ of the respondents were not sure whether they provide essential information or not. $7.8 \%$ of people feel that it doesn't provide useful details.

How do you trust the authenticity of E-commerce

sites?

550 responses

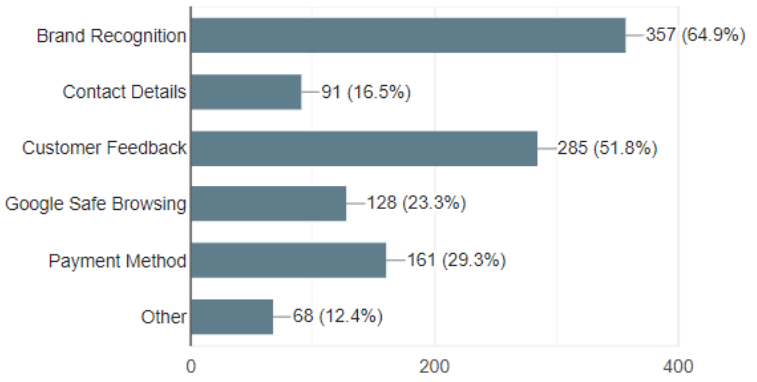

Fig 1.11 550 Responses. Based on the question "How do you trust the authenticity of e-commerce sites?"

Brand name is one of those brand elements which helps the consumers to differentiate the product from others while purchasing. As shown 357 respondents out of 550 trust the authenticity of E- commerce sites by its brand name. Whereas 285 people feel customer feedback is an important aspect to trust the authenticity.91 


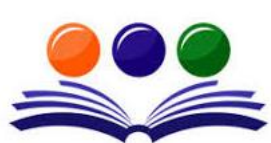

GRAND ACADEMIC PORTAL RESEARCH JOURNALS

\section{A GLOBAL JOURNAL OF SOCIAL SCIENCES}

( ISSN - 2581-5830 )

Impact Factor - SJIF - 4.998, IIFS - 4.375

Globally peer-reviewed and open access journal.

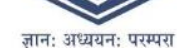

people feel contact details, 128 people feel Google safe browsing, 161 people feel payment method while trusting the veracity of E-commerce sites.

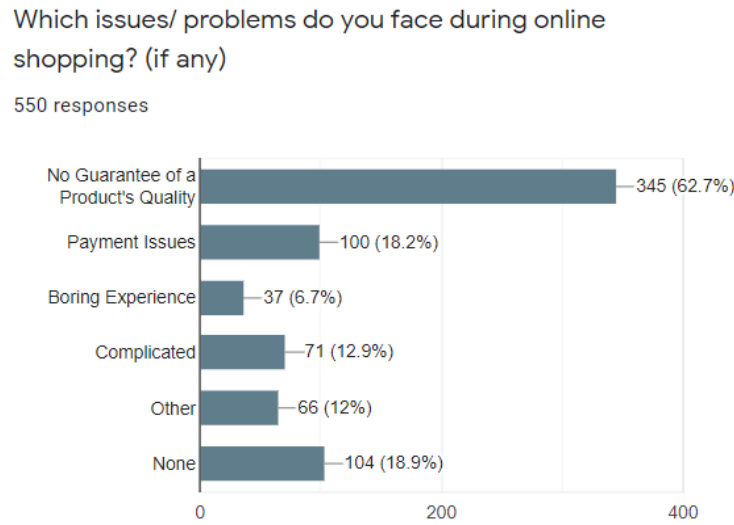

Fig 1.12 550 Responses. Based on the question "Which issues/ problems do you face during online shopping?"

As mentioned earlier, people feel that E- commerce sites do not provide essential information because of which people face difficulty during online shopping. No guarantee of product quality and payment issues was the major difficulty with $62.7 \%$ and $18.2 \%$ respondents respectively. Very few felt such sites were complicated and had boring experiences.
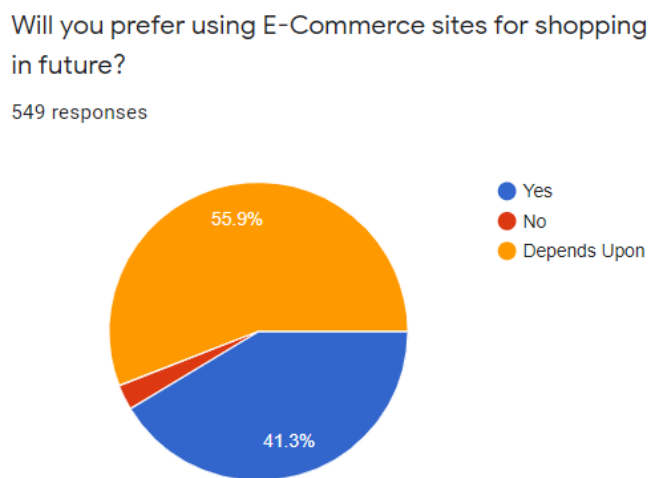

$$
\begin{aligned}
& \text { Yes } \\
& \text { No } \\
& \text { Depends Upon Product }
\end{aligned}
$$

Fig 1.13 550 Responses. Based on the question “Will you prefer using e- commerce sites for shopping in future?"

Quality of the product was considered a major aspect for people to use E-commerce sites in future with percentage of $55.9 \%$

\section{FINDINGS AND CONCLUSION}

The first case of the Covid-19 pandemic in the NCR of India was reported on March 2, 2020. The confirmed number of corona virus cases rose over 1.4 million as on $5^{\text {th }}$ June 2021, with over 24000 casualties and over 1.3 million recoveries in Delhi NCR. Since this virus spreads primarily between people who are in close contact with each other, it is advised by the health authorities for people to stay at their homes and not to go out unless the work is very urgent. In order to make people adhere to such guidelines, many State Governments among the Delhi Government had imposed lockdown in their states. This has led to increase in the rate of online shopping, particularly in the Delhi NCR.

Encapsulating the above methodology, the results of the research paper are that people have become aware of the benefits of e- business and they are slowly switching over this mode of business. They are ready to adopt EBusiness as an alternative to offline businesses. But, as stated earlier, the nature of the product was considered a major characteristic for people to use e-commerce sites in future with a percentage of 55.9\%.

Many prominent online retailers such as Amazon changed their ways of delivering their items. To comply with the regional requirements and social distancing norms, they had made delivery contactless or contact-free. Also, many food outlets such as McDonald's and Domino's Pizza have introduced contactless and safe delivery of food items with adequate social distancing measures. This also has led to the surge in rate of e-business. According to the Statista report, the most commonly purchased online items were food and groceries, personal hygiene products, and household cleaning products.

To sum up, e- business boosted up during the covid-19 pandemic. On behalf of the responses by 550 people of NCR, we can say that the future of e-business in NCR of India will be bright as more and more people are shifting towards online mode of business. 


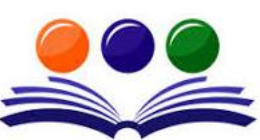

GRAND ACADEMIC PORTAL RESEARCH JOURNALS

\section{A GLOBAL JOURNAL OF SOCIAL SCIENCES}

( ISSN - 2581-5830 )

Impact Factor - SJIF - 4.998, IIFS - 4.375

Globally peer-reviewed and open access journal.

\section{REFERENCES}

\section{JOURNALS}

[1] L.T.T, Tran, "Leading the efficiency of e-commerce manifesto in the pandemic. In the Jou. of Retailing \& Costomer Services" 2020//

[2] Basit, H., H.M., A., Bhatti, Akram, Khan, Naqvi and A.Q., M. B. "E-Commerce drift in Coronavirus Pandemic. In the Intl. Jou. of Future Generation Transmission and Association, P.P. 1449-1452."2020//

[3] Hoque, A. , Hasanat, M.W., Anwar, F. A., Shikha, M., H.H, A. B. A., \& Tat, Hamid "Aftermath of Covid 19 on ebusiness in Malaysia. In the Asian Jou. of Multidisciplinary Studies P.P.85-90. "2020//

[4] Pantelimon, T.M., Posedaru, F.V., \& Georgescu, B.Ş. "Impact of adaptable e-commerce on GDP: A Comparative Analysis b/w Romania \& Germany \& how Covid-19 ascend the e-Commerce Activity Worldwide. Informatica Economica P.P. 27-41." 2020//

[5] K.M., \& Nor M. A. , Salem "Impact of Coronavirus on Consumer Conduct in Saudi Arabia: Shifting From Brick and Mortar Stores to e-commerce. In the Intl. Jou. of Scientific \& Tech. Research, P.P.15-28." 2020//

\section{ELECTRONIC REFERENCES}
[1] Investopedia
[2] Wikipedia
[3] Statista
[4] The Print 